\title{
Kurat, pattulangemine ja nõidus. Kristlike nõidade demonoloogia ja teoloogiline antropoloogia
}

Dieter Harmening

Viimasel ajal on nõidadest palju räägitud. Raadio ja televisioon on edastanud selleteemalisi päevakajalisi teateid lähikonnast, erialakongressid ja näitused on kaevunud probleemi sügavusse. Kirjutistega tutvudes võib märgata, et kui jutt on nõidadest, rää-gitakse tegelikult mitmesugustest nähtustest. Juba asjassepuutuv kultuskirjandus ähmastab nõia olemust. Hans-Peter Duerri essee "Kas nõiad oskavad lennata?" näitab, et isegi siis, kui nõidadest rää givad etnoloogid, usundi-ja mütoloogiauurijad, ei ole sugugi selge, kellest ikkagi juttu on. ${ }^{1}$

Kristlikul Õhtumaal räägitakse nõidadest enamasti seoses inkvisitsiooni ja kohtuga. Need on isikud, kellele heidetakse ette kahjustavat nõidumist, kristlikust usust taganemist ja kuradikummardamist. Selles suhtes erinevad nad religiooniajaloos käsitletavatest nõiakunsti tundvatest igapäevanõidadest ja levitatsioonis kahtlustatavatest. ${ }^{2}$ Nende olemasolu ei saa seletada analoogial põhinevate võrdlustega, vaid ainult nende erilise ajaloo taustal, nende ajalooliselt tingitud kuju põhjal. Kui tahame välja selgitada, mida mõeldakse kristlikul Õhtumaal nõia all ja mis on nõidade tagakiusamise taga, peame tundma nõiduse ja nõidade kujutamislugu.

Claude Lecouteux on koondmõistet 'nõid' käsitledes võtnud kokku euroopa "alama" mütoloogia teatud ilmingud. ${ }^{3}$ Siinjuures tuleb selgitada ka teoloogilist tausta, mille piires saab müütilised motiivid ühendada teatud kujuga, mille üle kirik ja ametivõimud on mõistnud kohut, lähtudes alustelt, mis pole üheselt kindlaks määratud.

Sellest, mida kujutasid endast nõiad kristlikus Euroopas, saab kõige paremini aimu Nõiahaamrit lugedes. Seal reastatud teemad pärinevad antud valdkonna õhtumaisest, õpetatud teoloogilisest traditsioonist, ${ }^{4}$ mitte teose autorite fantaasiatest, nagu vankumatult on väidetud. Autorite teeneks on, et nad koostasid käsiraamatulaadsele koondi juba kaua käibel olnud teatud liiki nõidade liigitusest. Ilmselt oli selle järele vajadus. 


\section{Dieter Harmening}

Käesolevas artiklis on nõidadega seotud väited jagatud mütoloogilisteks, demonoloogilisteks ja antropoloogilisteks. Nõia mütoloogia all vaadeldakse uskumusteateid deemonlikest inimestest ja motiividest, mis olid tuntud ka ilma nõiduseta: kahjustav maagia, vampirism, loomaks moondumine, lennuvõime jt. Need erakordselt levinud motiivid on tuntud küllap igas kultuuris ja sellega on autor tegelnud ühes oma eelmistest artiklitest (vt kommentaari 4).

Demonoloogia puhul tõstetakse esile õhtumaise õpetatud deemoniõpetuse osa, mis tugineb õpetustele deemonite kaasabil nõidumise võimalikkusest, tõelisusest ja mõjust.

Nõidade antropoloogia all vaadeldakse kujutelmi ja mõtisklusi naistele eelduslikult loomuomase nõidumisele kalduvuse teemadel.

\section{Demonoloogia}

Õhtumaise demonoloogia ja nõidusteooria mõistmiseks on vajalik hilisantiigi uusplatonistliku üksikasjalikum kosmoloogia tundmine.

Inimese hingeeluga seotud maagiline mõtlemine lähtub eeldusest, et sarnased asjad ja suhted mõjutavad üksteist. Nii nagu ühe inimese meeleseisund võib samasuguse seisundi esile kutsuda kellelgi teisel, samuti on ka välismaailma ilminguid üksteisega sarnasusseostes ja mõjuvad sümpaatiliselt (kaasatundvalt). Nõidumine on sellise kujutelma praktiseerimine ja seega alati kujundlik, sarnasusel rajanev tegevus, mille puhul sarnase mõjutamine sarnasega kutsub esile sarnast. Kus kujutelm sarnaste vastastikusest mõjust tehakse kosmilise seostatuse süstemaatiliseks printsiibiks, tekib struktuurilistest vaatekohtadest lähtuv maailmapilt. Selles on kõik korrastatud morfoloogiliste aspektide järgi ja omavahel vastastikku seotud.

Uusplatonistlik teoloogilis-loodusfilosoofiline spekulatsioon on välja arendanud sümpaatiliste struktuuride kosmoloogilise süsteemi, mida käsitlesin põgusalt artiklis õhtumaisest maagiast. ${ }^{5}$ Selle mudeli järgi on kõik kosmilised elemendid korrastatud erinevateks "ridadeks", kus "ülevalt" (jumaliku vallast) "alla" (maise vallani) mõjuvad vastaspoole alged ja jõud. Õhtumaise nõiduse- ja maagiakujutelma mõistmiseks on nende seoste tundmine oluline.

Proklos (u 410-484) on sellise kosmose ülesehitust kirjeldanud järgmiselt: 
Kõikide hingestatud olendite looja on demiurg. Hingestatud olendite ahela ühes otsas on jumalad, teises maapealsed surelikud inimesed ja loomad. Et aga üsna võimatu on uskuda, et looja kohe ja vahetult pärast jumalaid, hingestatud olendite kõrgeimat astet, oleks loonud surelikud, s.t madalaima astme, tuleb paratamatult aktsepteerida vaheliikmeid.

Need vaheolendid moodustavad kolmikud: eristatakse ingleid, deemoneid ja kangelasi. Need kolm liiki kuuluvad kokku kõrgemalseisvate jumalatega, kusjuures iga jumalat ümbritseb talle omane hulk ingleid, deemoneid ja kangelasi, keda see jumal juhib ja kelle loomus ja põhiolemus peegelduvad omakorda talle järgnevates vaheolendites. Seetõttu on inglite, deemonite ja kangelaste liike sama palju kui on jumalate liike.

Seejärel alustab Proklos uuesti deemonitega ja esitab edasised alamklassid, mis on oma funktsioonide poolest erinevad, nii et ühe klassi osaks on eksistentsieelsete hingede sidumine nende tähtedega, teise osaks on juhtida hingede kehadesse laskumist ja jumaliku juurde tõusmist, kolmanda osaks korraldada jumalate ja nähtava looduse ühendamist.

Neljas klass annab erinevatele olenditele maal elu ja mõistuse, viies vastutab nende olendite puhtkehalise poole eest ning lõpetuseks kuues kaitseb ja hoiab elutut mateeriat ja hoolitseb selle eest, et maa peal püsiks juba ähmastuma kippuv pilt jumalikest ideedest. Sel moel on nad ka kõike üksteisega siduva sümpaatia kaitsjad ja hoidjad.

Kellel on teadmine jumalate, inglite, deemonite ja kangelaste olemusest; kes teab, millised loomad, taimed, kivid jne on talle sümpaatsed või antipaatsed, ja lõpuks, ka nende "õigeid nimesid", see saab sundida nad kõik oma teenistusse. ${ }^{6}$

Selle uusplatonistliku kosmoloogilise mudeli järgi tähendab nõidumine seega jumalike mõjude ja jõudude kasutamist, mis on osaliselt olemas kosmose erinevates elementides ja mille iseloom vastab eesmärgile, mida soovitakse saavutada: nii kasutatakse Veenust ja tema juurde kuuluvaid elemente kõige armastusega seotu puhul, Marssi riiu, sõja, surma jms tarbeks. 


\section{Dieter Harmening}

Varakristlus võttis selle skeemi ja deemonliku maailma kujutelma üle ja kohandas ümber: deemonites nähti langenud ingleid ja nende kosmilises asupaigas kohta, kuhu nad ülevalt olid langenud. Olles taevast minema kihutatud, püüdvat nad nüüd inimesi eksitada, kõike selleks, et olla austatud nagu jumalad. ${ }^{7}$ Võime petta tulenevat nende erilisest loomusest. Kuivõrd nad elutsevad õhus, on neil ka õhusarnane keha. Ja nii nagu õhus toimub igasugune liikumine väga kiiresti, võivad ka nemad suure kiirusega kohta vahetada. ${ }^{8}$ Õhukeha võimaldab neil inimestesse sisse tungida, neid piinata või neile pettepilte ette manada. ${ }^{9}$ Kuna nad suudavad siia-sinna lennata, kogevad nad ka rohkem, kui inimene on võimeline teada saama. ${ }^{10}$ Siia lisandub asjaolu, et nad on oma kõrge ea tõttu omandanud ka rohkem teadmisi, kui see on võimalik inimesel tema lühikese elu jooksul. ${ }^{11}$ Pealegi olevat neil teravamad meeled. ${ }^{12}$ Vaimuloomuse intellektuaalsed eelised annavad neile võime pettusteks. Nad olevat loonud nõidumise ja maagia, juurutanud astroloogilised ja selgeltnägemise kunstid. ${ }^{13}$ Augustinuse järgi on nad võimelised ka imesid tegema: kas need on aga ainult pelgad silmapetted ja hanekstõmbamised või toimub see tänu nende võlukunstidele, selles lähevad arvamused siiski lahku. ${ }^{14}$ Nende tõekuulutused ja ennustused puudutavad igatahes üksnes teadmisi inimese eest varjatud asjaoludest, mida nemad võivad kiiremini tajuda. Muidu kuulutavad nad ette eelkõige seda, mida nad ise sepitsevad ja siis ka ellu viivad (nt haiguste esilekutsumine ${ }^{15}$ ), või seda, mida nad teatud märkide põhjal ära tunnevad, kuid mida inimene näha ei suuda. ${ }^{16}$

Paganlike deemonite iseloomu on seega käsitatud küll täiesti negatiivselt, nende väes ja mõjus maailmale pole aga siiski kaheldud.

Jumalariigis kirjutab Augustinus Veenuse templis asuva kustumatu lambi fenomenist. See kirjapanek ei ole huvitav üksnes demonoloogia seisukohast, vaid sealt on võimalik välja lugeda ka erilist arusaama deemonite mõjuvõimest, mis saab kuradisobingu idee põhialuseks. Augustinus kirjutab: "Nimelt lisame me sellele kustumatule laternale ka mitmed teised imed, inimlike ja maagiliste, s.t deemonlike kunstide imed, mida toimetavad inimesed või siis saadavad suurel hulgal korda ainult deemonid: neid maha salata tähendaks ju vasturääkimist pühade raamatute tõele, millesse me usume. Selle valgusti juures kasutatakse inimese leiutatud kunstlikku asbestist mehhanismi või on see valmistatud 
maagilise kunsti abil, mille tõttu inimesed lampi tolles templis uudistavad, või ilmutas mõni deemon end Veenuse nime all nii mõjusalt, et see imemärk sai inimestele nähtavaks ja kestis pikemat aega. Kuid objektid, milles deemonid viibivad, pole mitte nende, vaid Jumala loodud, ja deemonid meelitatakse ligi erinevate, nende enda eelistatud meelelahutustega; mitte kui loomi toiduga, vaid kui vaime sümbolitega, mis vastavad iga üksiku kalduvusele. Näiteks igasuguste kivide, taimede, puude, loomade, laulude ja tavanditega. Sellest tulenevad siis maagilised kunstid [---]. Niisiis on väga palju deemonite tegusid [---]. Kui nimelt juba ebapuhtad deemonid selliseid asju võivad korda saata, siis kui palju võimsam neist kõikidest on Jumal, kes on loonud ka need inglid, suurimate imede esilekutsujad! On palju ja suuri imeasju, mida kreeklane mechanémataks nimetab ja mis tekivad inimliku kunsti abil, endale Jumala loomingu kuulekaks tegemise abil. Seetõttu peavad inimesed, kes neid läbi ei näe, neid jumalikeks. Seepärast võis juhtuda, et mõnes templis hoiti põranda alla ja lae peale paigutatud vastava suurusega magnetkivide abil rauast ebajumalapilti õhus hõljuvana. Et keegi magnetite olemasolust ei teadnud, peeti seda nõiduseks. Ja midagi sarnast võis ka, nagu juba öeldud, olla mõni osav mees teinud asbestkiviga nimetatud Veenuse tule puhul. Nõidujate, keda meie pühakiri nimetab mürgisegajaiks ja needjaiks, niisuguseid tegusid mõistsid deemonid sedavõrd arendada, et kuulus luuletaja annab edasi üksnes üldise arusaama, kui ta ütleb ühe seesuguses kunstis kogenud naise kohta järgmist:

Mulle too teadjatar teatas, tal suutvat laul iga hinge
rõomuma panna või panna ta nukralt nutma ja kurtma;
vee võib taandada jõel, võib muuta ka tähtedel suuna,
mardused maa alt toob, maa jalgade all avab äkki
mustjaks taarnaks ja mäelt toob laskuma ladvakad tammed."17,18

Deemonlikud imed pole niisiis tõelised imed - Augustinus mõistab neid kui deemonite erakordsel intelligentsil põhinevaid tehnikaimesid. See, mida nimetatakse maagiaks ja nõiduseks, on seega deemonite tehnika või vähemalt põhineb nende tehnoloogial. See, mida deemonid esile kutsuvad, on tehnilised saavutused või, nagu kreeklane ütleb, mechanémata. Küsimuse puhul, kuidas deemonlikku tehnilist teadmist endale kasulikuks teha, on aga oluline see, mille Augustinus toob välja De doctrina christianas. ${ }^{19}$ Ta käsitleb seal küsimust, mil määral on kristlasele lubatud paganlike teadmis- 


\section{Dieter Harmening}

te harrastamine. Sellele vastamiseks on vaja metoodilisi põhimõtteid, mis sobiksid inimliku teadmise koguhulga liigitamiseks, et jõuda üksikute teaduste hindamiseni. Siinpuhul teeb ta vahet asjade (res) ja märkide (signa) vahel. Teises raamatus arutleb ta märkide üle: see on sümbol, mis johtuvalt oma loomusest viitab peale meeltega tajutava välimuse veel mingile mõttele. Näiteks jälge nähes mõtleme, et on möödunud see loom, kelle jälge me näeme; või suitsu nähes saame aru, et ka tuli on lähedal; kuuldes mõne looma häält, võime teha selle põhjal järelduse tema meeleolu kohta; sõjasarve hääle järgi saavad sõdurid teada, kas neil tuleb edasi liikuda, taanduda või sooritada mõni lahingumanööver. Seega võib eristada kahte liiki märke: loomulikud märgid (signa naturalia) ja antud märgid (signa data). Näiteks lõkkesuits või loomajälg on loomulik, sõjasarvehüüd aga antud märk.

Inimeste seas on tähtsaimateks märkideks sõnad ja sõnade edastamiseks on omakorda märgid - kirjatähed. Augustinus arendab siinkohal põhjalikumalt edasi seisukohti, millele ta raamatus Jumalariigist ainult vihjab. Nõiduslikke vahendeid ja tegevusi tuleb käsitada asjade võrdkujude ja märkidena. Need on selleks, et deemonitega ühendust võtta. Nii nagu keel on inimestel enda arusaadavaks tegemise teenistuses ja üksikutel tähtedel, silpidel ja sõnadel pole iseenesest mingit tähendust, vaid need saavad oma tähistava jõu alles seeläbi, kui nende tähenduses kokku lepitakse (n.-ö 'kõneleping' sõlmitakse), nii ei ole ka nõiduse vahenditel mingit tähendust iseenesest, vaid ainult siis, kui neid kasutatakse teatud keele sõnadena deemonitega suhtlemisel.

Nõidus on seega kokkuleppeliste märkide kogum, mida saab kasutada deemonitega suhtlemiseks. Nii nagu keel põhineb inimestevahelisel kokkuleppel ja eeldab sellise seose vaikivat tunnustamist, nii põhineb ka nõidus teatud kommunikatiivsel lepingul deemonitega. Kuid mis muud on lepingu sõlmimine deemonitega kui deemonitekultus, ebajumalakummardamine? Nõidus ja ebajumalakummardamine on seega üks ja seesama.

See keskajal ja järgnevatel aastasadadel tõsiste tagajärgedega teooria nõidumisest kui keelest, mille abil suheldakse deemonitega, puudutab eelkõige mittemeditsiinilisi seoseid (ligaturae) ja ravivahendeid (remedia), isikuid, amulette ja kombeid. Näiteks selliseid: "Sellele, kes luksub, [tuleb] öelda, et ta peab parema käega vasemat pöialt hoidma." 20 
Aquino Thomas jätkab hiljem uuesti augustiinlikku teooriat maagilis-uskumuslike manipulatsioonide lepingulaadsusest ja vahendab seda oma Summa theologiaes kesk- ja uusaja nõiateoreetikuile. Eriti oluline on tema lepingu mõiste laiendamine. Nii nagu Augustinus, mõistab ka Aquino Thomas nõiduse vahendeid ja tegevusi kui inimeste ja deemonite vahelise keele elemente. Iga keelekasutus eeldab aga keeleliste tähenduste sidusust. Enne, kui üksteisega üleüldse saab mõtestatult rääkida, tuleb seetõttu kokku leppida sõnade tähenduses. Kõnet vallata ja arusaadavalt rääkida saab aga ka ilma sellist siduvat kokkulepet kinnitamata: seda eeldatakse vaikimisi.

Sama kehtib ka ebausuvahendite kasutamise kohta: see eeldab "vaikivat" kokkulepet (pactum tacitum) nende tähendussisu kohta seni, kuni tegutseja ei teadvusta endale "keelelepingut" deemonitega. Niipea aga, kui deemonitega suhtlemise võimalusi teadlikult kasutatakse, saab see aluseks "väljaöeldud kokkuleppele" (pactum expressum) nendega. Seega ei saa ükski ebausu manipulatsioon toimuda deemonitega lepingut sõlmimata, ükskõik kas deemonid tõugatakse tegudele "selgesõnalise kutsega" (expressa invocatio) või ilma selleta (absque expressa invocatione). Seega põhineb igasugune nõidus teadvustatud või teadvustamata sobingul deemonitega (pactum significationum cum daemonibus initum). ${ }^{21}$

Põhinedes õpetusel iga ebausuteo mõjususest ja eeldusel, et kõik, mis maailmas juhtub, võib juhtuda ka deemonite tõttu (Omnia, quae visibiliter fiunt in hoc mundo, possunt fieri per daemones ${ }^{22}$ ), on ebausk muudetud jubedaks ohuks - nii on seda tajunud ka hiliskeskaegne ja uusaegne nõiakujutlus.

Eelnevale lisandub veel kuradikultus, mis hakkab õhtumaise nõiajahi arenguloos etendama üha suuremat rolli. Nõiasabati mõiste alla koondatud kultuse vormid on erinevad.

Teoloogiliselt ei tohi kuradikultuse ideed vaadelda pelgalt kuradilepingu teooria edasiarendusena, sest Augustinus tugineb oma nõiduse keeleteoreetilise iseloomustusena ka sakramenditeoloogilistele arutlustele. Olles märgiline tegevus, on nõidus võrreldav sakramentaalse märgikasutusega. Järelikult võib nõidumisvahendeid käsitada kui sakramente deemonikummardamisele poolehoiu väljendamiseks. Seega kehtib ka siin reegel, et "inimesi ei saa viia mingi usu tunnistamiseni teisiti kui seotuse kaudu ühiste nähtavate märkide ehk sakramentidega." ${ }^{23}$ De diversis quaestionibus ad Simlicianumis $^{24}$ räägib Augustinus lausa magicis sacrisest, käsitledes 
Pythonissa Saamueli needmist. Ebausumärgi ja sakramendi paralleelsus viitab, et nõia- ja nõiakunstiteooria tagajärjed on samad sakramendiõpetusega. Kui sakramendil on "kirikutrajav funktsioon jajõud", ${ }^{25}$ kehtib see ka ebausumärgi kohta: praktiseeriv ebausklik ja nõiduja määratleb end seega kui teatud kiriku liige, ja nimelt deemonliku kiriku oma.

\section{Antropoloogia}

Hiljemalt 18. sajandi valgustusajastu ebausukriitikas kohtab silmatorkavalt sageli ebausu omistamist naistele, eriti "vanadele naistele". Johann Georg Schmidti 18. sajandi algusest pärinev paljutsiteeritud ja -loetud neljaköiteline ebausupoleemika Mukitud seelikufilosoofia ${ }^{26}$ seostab ebausu juba oma pealkirjas "üliarukate", niisiis paremal juhul pahaaimamatute naistega ja lisab sellele tähelepanekuid "vanade naiste vanaeidelikest valedest" ${ }^{27}$

Ületamatud on Nõiahaamri ${ }^{28}$ teemakohased heietused ja kogud. Neid aga pelgalt autorite "õeluse, rumaluse, halastamatuse, silmakirjalikkuse, salakavaluse, ebapuhtuse, jampslikkuse" 29 arvele panna oleks möödavaatamine asjaolust, et Nõiahaamer pärineb suures osas Õhtumaa õpetatud ja teoloogilisest kirjandusest ning teeb oma temaatilise ühtepõimimise kaudu nähtavaks selle, mis eraldi võetuna ei tarvitse eriti silma torgata: pidades silmas naiste arvatavat erilist kalduvust nõidumisele, konstateeritakse: "Mis puutub aru või vaimse mõistmist, näivad nad [naised] olevat teisest liigist kui mehed, millele viitavad autoriteedid, üks teatav põhjus ja erinevad näited pühakirjas."30

Nõiahaamrist veidi vähemhaarava arutluse ja süüdistuse naise kui ebausu suurima edendaja kohta esitab iga ebausuvastane seisukohavõtt (niikaua kui Õhtumaa pinnal üldse saab rääkida ebausukriitikast).

Nimetagem siinkohal mõningaid, näiteks Pariisi Wilhelmit, ${ }^{31}$ Frankfurdi Johannest ${ }^{32}$ ja Heidelbergi magister Nikolaus Jauerit, ${ }^{33}$ kelle arvukates käsikirjades levitatud traktaat De superstitionibus esindab kindlat arvamust, et ebausu levitajad on ennekõike naised. Landskrona Stephanil leidub Taevatees osutus, et "patused vanad naised ja mõned kergemeelsed uskmatud ning rumalad inimesed on (selle) välja mõelnud" [sunder alte weiber unnd etlich leichtfertig ungelaubig und naerrisch leüt [das] erdacht habendt. $]^{34}$ 
Frankfurdi Johannes paneb naiseliku kalduvuse nõidusele juba selgesõnaliselt tema arvates naistele omase intelligentsi puudumise arvele. $^{35}$

Mõisteajalooliselt on see kõigest üks osa mõistest "ebausklik eideke" (superstitiosae mulierculae), nagu teda tunneb juba Hieronymus: ${ }^{36}$ naise väidetav loomupärane intelligentsi ja aru puudus. Ka Lactantius usub, et kalduvust ebausule tuleb pidada naiseliku loomuse nõrkuste hulka kuuluvaks. ${ }^{37}$

Lactantiuse väljendit superstitio anilis kasutasid väga sageli juba Cicero ja teised antiikkirjanikud ja see võimendab väidet naiselikust kalduvusest ebausule, nimetades lisapõhjusena vanadusnõtrust. $^{38}$

Selleks, et mõista ebausklikkuse antropoloogiat õigesti, tuleb selgusele jõuda etümoloogilistes implikatsioonides, mis sisalduvad mõistes anilis superstitio ('vananaiste ebausk'). Ladinakeelse supertitio etümoloogia oli ilmselt juba varakult risustunud. Lihtsate koostisosade super ja stare seos lähtub järgmistest keelelistest algetest: 1) sõnast superstes, mis tähendab sama, mis 'üle olema', 'üleelanu olema' ja 2) sõnast superstitiosus selle varem käibel olnud tähenduses 'kartlik', eriti aga 'liialdatult kartlik' religiooni asjus.

Cicero on need, ilmsesti ka oma tähenduselt suguluses olevad sõnad, etümoloogiliselt ühendanud. Ta selgitab seda võrdluses sõna religiosus tähendussisuga: neid, kes päevast päeva põlvitavad, paluvad ja ohverdavad, et nende lapsed superstites oleksid, "ellu jääksid", nimetatakse seetõttu superstitiosi; aga neid, kes järgivad hoolikalt kõike jumalakultuse juurde kuuluvat, nimetatakse religiosi, mis tähendab sama mis "need, kes midagi hoolsalt järgivad". ${ }^{39}$ Sevilla Isidor, 6.-7. sajandi Hispaania kirikuisa, tutvustas seda selgitust keskajale. ${ }^{40}$

Cicero näeb niisiis homo superstitiosuse, 'ebauskliku inimese' tunnusena tema kartust ja pelglikkust, nagu seda antud seoses leidub ennekõike vanade naiste juures. Raamatus Ettekuulutamisest kirjeldab ta ebauskliku hirmuerutuse seisundit järgmiselt: "Samuti, nagu [meie] kohus on religiooni levitada, on [meie] kohus ka kõik ebausuidud välja juurida. Sest ta on võimukas ähvardaja ja pealetungija. Pööra end kuhu tahad, ta järgneb sulle: sa võid kuulda võtta nägijat või ennet, võid ohverdada või lindude järgi ennustada, võid ringi vaadata kaldealase või haruspeksi järele, võib tulla äikest või võivad sähvida põuavälgud või lööb pikne kuhugi sisse, kord on miski võlumärgina maailma tulnud või juhtu- 


\section{Dieter Harmening}

nud (ja kõigest sellest peab midagi sagedasti toimuma) - kunagi ei saa sa kindla ja rahuliku vaimuga paigale jääda." ${ }^{41}$

Selgelt tõuseb esiplaanile seos hirmu ja kartusega, mis Cicero arvates väljendub sõnas superstitio. Mõlemad on tema arvates olulised ebausu elemendid ja ebauskliku inimese omadused. Teisal formuleerib ta napilt: Superstitio, qua qui est imbutus, quietus esse numquam potest ${ }^{42}$ ('Mitte kunagi ei saa olla rahulik keegi, kes on ebausust täidetud').

"Vananaiste ebausu" mõisteringi kuulub ka kategooria "vananaiste jutt", nagu näiteks tuleks tõlkida Ambrosiuse väljendit aniles fabulae, ${ }^{43}$ samuti Basileios Suure "muinasjututädi" kuju. ${ }^{44}$ Antiikja keskaja kristlike kirjanike sarnaste nimetuste kasutamises on paiguti hoomatav antropoloogilisest raamistikust rohkemat. Näiteks võrdleb Turini Maximus "vana luulu" ja "paganlikke narrusi" vanaema jutustustega. ${ }^{45}$

Paganlust ei peeta "vanaemaks" legitiimse esivanema mõttes, vaid "vanaemaks", kes jutustab uskumatuid lugusid ja - mida apologeetiline poleemika ei väsi varieerimast - kõige lapsikumaid, labasemaid petujutte ja väljamõeldisi.

Paganlus pole midagi muud kui suur narrus, see on õones ja tühi, sigitatud vaimust, mis on sarnane "vanade naiste nõrgamõistuslikkusele”. Paganlust iseloomustatakse hulga iseloomulike epiteetidega: mõttetu, tähendusetu, pime, mittemidagiaimav, juhm, ebausaldusväärne, kehtetu, tühi, alp, naeruväärne, vananaiselik, valelik, nõdrameelne ja hull. ${ }^{46}$ Lisanduvad märkused selle kohta, et paganluse ja ebausu üle võib üksnes naerda ja et nad peaksid õigupoolest oma mõttetute ettekujutuste pärast häbist punastama. ${ }^{47}$

On raske uskuda, et selliste mõtteavaldustega oleks mõeldud ainult juhmust, mille vastu isegi jumalad asjatult võitlevad. Etteheide intellektuaalse puudulikkuse kohta suunab kogu kompleksi error-ignorantia-insipia-stultitia vaatlema laiemas seoses. Vähemalt tekib küsimus, kas esiplaanil asetsev süüdistamine "eksituses", "juhmuses" ja "narruses" ei varja enda taga lihtsalt põhimõtteliselt pagana ja ebauskliku loomusest sugenevat juhmuse vormi.

Õhtumaise pagana-ja ebausukriitika seisukohast on oluline Braga peapiiskopi Martini (515-580) näidisjutlus misjonäridele esitamiseks "harimatute" (rustici) juures, kes, olles ristitud, kummardavad edasi ebajumalaid. ${ }^{48}$ Braga Martin selgitab selles paganluse päritolu, olemust ja ajalugu järgnevalt: Jumal lõi inglid koos taeva ja maaga. Neist üks ei tahtnud aga Jumalat, oma loojat, austada, vaid pidas 
ennast jumalasarnaseks. Selle kõrkuse (superbia) eest visati ta koos oma liitlastega taevast alla ja temast sai sünge kurat, tema vandeseltslastest deemonid. Selle järel vormis Jumal inimese, et võtta teda seniks, kui ta käsku täidab, surematuna truudusetute inglite asemel taevasse. Seepeale läks kurat inimese peale kadedaks ja veenis teda Jumala käsust üle astuma, mispeale inimene aeti paradiisist välja - pagendusse maa peale, kus ta nüüd vaeva ja valu peab kannatama. Esimeste inimeste järeltulijad unustasid oma looja ja saatsid korda mitmeid pahategusid, nii et Jumal sai vihaseks ja uputas kõik peale Noa ja tema perekonna suures veetulvas. Pärast veeuputust, kui inimesed hakkasid uuesti maapinda asustama, unustasid nad uuesti oma looja ja jumalikustasid loodust. Ühed palusid päikest, teised kuud, tähti, tuld või merd, sest nad uskusid, et mitte Jumal pole neid asju loonud, vaid nad on pigemini iseenesest tekkinud ja ise jumalad.

Nii pettis kurat ja kogu tema liitlaskond teadmatuid inimesi (ignaros homines). Nad näitasid end erineval kujul, rääkisid inimestega ja saavutasid selle, et neid austati kui jumalaid ja neile toodi mägedel ja metsades ohvreid. Seejuures võtsid nad endale kurjade inimeste nimed, kes olid oma elu kuritegudega mööda saatnud: nii ütles üks enda olevat Jupiteri, teine deemon nimetas end Marsiks, kolmas Merkuuriks, neljas Saturniks ja üks deemon väitis end olevat Veenus.

See õpetus ebajumalakummardamise allika kohta paistab silma euhemeeriliste ja demonoloogiliste tõlgenduselementide seostamine poolest, nagu ka tõelise ebajumalakummardamise ja kreatuurijumaldamise eristamise poolest. Ebajumalakummardamisele eelneb Martini arvates kreatuurijumaldamine ja sellele inimeste moraalne rikutus. Esimeste inimeste järeltulijad unustasid Jumala, oma looja, ja saatsid korda palju patutegusid, iseloomustab Martin veeuputuse-eelset inimkonda. Loodusekultusest või ebajumalakummardamisest veel juttu pole, vaid üksnes inimkonna eetilisest langusest, mis põhineb Jumala unustamisel. Pärast veeuputust kasvas jumalaunustus vabatahtlikuks jumalahülgamiseks (dimisso creatore), mille tagajärjeks oli Jumala mittetundmisel põhinev kreatuurijumaldamine: usuti, et päike, kuu, tähed, tuli ja vesi on iseenesest tekkinud ja nad on jumalad. Alles nüüd sekkusid deemonid, nähes, et inimkond oli kaotanud teadmise (ignaros homines) ja oli eksiteadmises loodusest ja maailma algusest.

Ebajumalakummardamisse langenud inimesi nimetab Martin homines ignorantes deum ja ignorantes rustici. See kehtib nii eel- 


\section{Dieter Harmening}

kristliku inimkonna kui ka usust taganenud kristlaste kohta. Idolaatrilist langust näitavad edaspidigi vähene usk ja kahtlused: non ex toto corde in fide Christi credunt. Ebauskliku inimese ignorantia - seda näitas Braga Martini näidisjutlus väga selgelt - ulatub seega vahetult tagasi esimese inimese langemiseni, mis on viinud inimliku aru ja Jumala ning maailma loomuse tundmise tuhmumisele. See seisukoht kuulub traditsioonilisse õpetusvaramusse paradiisipatu tagajärgedest. Ignorantia on selle "vana patu"49 tagajärg, see on pärispatuse inimese rikutud loomuse pitser: niimoodi arult nõrgestatuna ja teadmatuseuttu mähituna ${ }^{50}$ olevat inimkond jõudnud looduse jumalikustamiseni ja selle tagajärjel sattunud surnud inimeste ja elutute nukkude kummardamisse. ${ }^{51}$

Ükskõik kui diferentseeritud ja erinevad on olnud hiliskeskaja lõpuni õpetused esimese patu tagajärgedest, kohtab kõikjal, kus selle müütilise languse üle juureldakse, mõtet, et pattulangemine on viinud mõistuse üleüldise tuhmumise ning Jumala, maailma ja inimloomuse hindamise nõrgenemise, teadmatuse ja eksimuseni. Selleski osas on Augustinusel olnud keskaja pärispatu-teoloogiale suurim mõju. Teoses Jumalariigist toob Augustinus esile, kuidas inimest paradiisis peteti ja ahvatleti. ${ }^{52}$ Langenud inglid, tahtes inimest Jumalast eemale meelitada, teadsid hästi, et Aadamat nad ahvatleda ei saa, sest too oli täiesti eksimatu, varustatud kõrgete teadmiste, kõikmõeldavate vaimsete ja kehaliste eelistega. Teda poleks deemonid suutnud petta. Käsitus esimese inimese intellektuaalsetest eelistest ei ole Augustinuse leid. Umbes pool sajandit varem oli Salamise Epiphanios sama väljendanud oma teoses Hereetikute vastu: "Muidugi pöördus Kurat, kuna ta ei suutnud petta mehelikku hinge, mida Jumal oli tugevdanud Jumala tõetundmisega, naise poole, seega ilmselgelt inimese teadmatuse poole; ja et ta ei saanud oma mängu mängida tugeva tarkusega, proovis ta ligi meelitada neid, kelle (vaimu) tuhmistas teadmatuse pimedus. Nii riputas ta end järelejätmatult naiselike mõtete külge, liiga suure iha ja soovide külge, s.t naiseliku teadmatuse külge inimese juures; kindla, aga püsiva hinge ees põrkub ta tagasi, sellise ees, mis õpetab harmoonilisi ja ainulisi teadmisi ja tunneb looduse seaduse põhjal Jumalat ennast." 53

Vähemalt selles osas, mis puudutab esimese inimese intellektuaalsete võimete hindamist, said varakristlikud kirjanikud jätkata eelkristlikke vaateid. Ka kreeka filosoofid olid veendunud selles, et "vanad" olid iseenda loomusest ja maailmast rohkem teadnud. Stoik 
Poseidonios, Cicero õpetaja, iseloomustab algaega nii: "Kuna inimestel oli vahetu, veel igasugusest võõrandumisest või äralangemisest rikkumatu kokkupuude jumalikuga, maailma logosega [--]. Samal põhjusel on sellele, mida ütlesid välja endisaja targad, iseloomulik eriliselt tõene sisu." ${ }^{54}$ Hiljem on uusplatonismile lähedalseisev platoonik Numenios Apameast väljendanud veendumust, et kui tahetakse leida tõde, tuleb küsitleda lugupeetud rahvaid - braahmaneid, juute, maage (= kaldealasi) ja egiptlasi. ${ }^{55}$ Juba Platon on märkinud vanaaja tarku kui dispuudi tähtsaid osalisi: "Vanad" on andnud asjadele nende nimed ${ }^{56}$ ja vahendanud meile teadmist hinge surematusest.57 "Vanad" olid tõele lähedal, kuna nad olid veel lähedal lätetele ja jumalatele. ${ }^{58}$ Augustinus arendab teoses Jumalariigist oppetust inimese langemisest paradiisis: "Pärast seda, kui aga too upsakas ja seetõttu kade ingel oli oma kõrkuse tõttu Jumalast ära pöördunud, tahtes oma türanlikus uhkuses meelsamini alluvate üle rõõmustada kui ise alluv olla, ja ta vaimsest paradiisist välja tõugati, püüdles ta võrgutava kavalusega inimese meele järele, keda ta, kuna ta ise oli langenud, tolle püsivuse pärast kadestas. Seega valis ta endale kehalises paradiisis, kus koos mõlema inimese - mehe ja naisega - jooksid ringi ka ülejäänud vagurad ja kahjutud maised elusolendid, välja mao, libeda, keerdkäikudes osava, just tema teoks sobiva looma, kes pidi teda kõnemehena aitama. Vaimses õeluses tegi ta oma inglivälimuse ja erakordse loomuse abil mao endale kuulekaks, et teda oma tööriistana kasutada, ja alustas niimoodi petukõnet naisega. Mõeldes, et mees pole nii kergeusklik ja et teda ei saa tema enese eksimise läbi petta, vaid teda saab ainult võõra eksimise läbi murda, tegi ta algust inimpaari alama osaga, et niimoodi järgemööda tervikuni jõuda." 59

Petta sai ainult Eevat, kes ei olnud osaline Aadama eksimatuses. Eeva astus Jumala käsust üle ja tõukas, pärast seda, kui ta oli ka Aadamat veennud, kogu inimsoo suurimasse viletsusse: "Tol ajal sõi inimene inglileiba, mille järele ta nüüd ihaleb, praegu sööb ta valuleiba, mida ta tookord ei tundnud. Valud, inimeste üldine lein, üleüldine Aadama poegade halin! Too röhitses kõhutäiusest, meie luksume näljast [---]. Miks ta ei hoidnud meile seda, millest me nii rõhuvalt puudust tunneme; ta võinuks seda ju kergesti? Miks on ta nõnda meie eest valguse peitnud ja meid pimedusega katnud?"60

1487. aastal ilmunud Nõiahaamer ${ }^{61}$ esindab - teisiti, kui seda tahaksid poleemilised mahategemised, mis näitavad raamatu auto- 


\section{Dieter Harmening}

rit Heinrich Kramerit (Institorist) nõiajahi "kirjutuslauakurjategijana" - augustiinlikku pärispatuõpetust ja selle antropoloogilist traditsiooni, mis ilmneb arutlustest naise kergeusklikkuse üle. Viimane tõstetakse esile kui naise nõidusele kaldumise olulisim põhjus. Juurde lisatakse vastavad tähelepanekud naise loomulike intellektuaalsete puudujääkide kohta: "Sest mis puutub arusse või vaimse mõistmisse, näivad nad [naised] olevat teisest liigist kui mehed, millele viitavad autoriteedid, üks teatav põhjus ja erinevad näited pühakirjas." ${ }^{2}$ Tuginedes Terentiusele - "Naised on nõrga aruga, peaaegu nagu lapsed"63 - näitab Nõiahaamer aru nappuse ja kergeusklikkuse tihedat seotust. Viimasele viitavat juba femina etümoloogia. Sõna olevat tuletatav osadest $f e$, see tähendab fides ja minus ('vähem') ning tähendavat seda, 'kel vähem usku'. ${ }^{64} \mathrm{Ta}$ jätkab: "Niisiis on naine loomult nõrk, kuna ta kiiremini usus kahtleb ja ka kiiremini usku salgab, mis on nõiduse põhialus." ${ }^{55}$

Võttes kokku erinevad kujutlused, mis on aluseks oletusele naiste antropoloogiliselt põhjendatud kalduvusest nõidumisele, saame järgmise loetelu.

1. Juba eelkristlikud kirjanikud omistasid naistele, eriti vanadele naistele, erilist ebausulähedust. Selle põhjuseks näib olevat silmatorkav kartlikkus ja erutatus religiooni puutuva suhtes ehk anilis superstitio. Sellest kujutlemast on tuletatud veel mõiste "vananaiste ebausk".

2. "Vananaiste ebausku", nagu see väljendub näiteks "vananaiste juttudes”, peab Basileios Suur paganluse metafooriks. Paganluse müüdid olevat samamoodi mõttetud nagu meie vanaemade muinasjutud. Paganlust nimetatakse "vanaks eksituseks" (error antiquus) ja "narruseks" (stultitia). Siiski on sellega mõeldud ilmselgelt rohkemat kui suudab väljendada metafoor.

3. "Rumalus" ja "narrus" ilmnevad nimelt kui paganlusele omased jooned, sest algusest peale põhineb paganlus esimese inimese "teadmatusel" (ignorantia).

4. Ühelt poolt mõistetakse ignorantiat kui esimese patu tagajärge, teiselt poolt kirjeldatakse esimest pattu kui esimese naise loomuliku arunappuse tagajärge, sest Aadama küljeluust tehtud Eevat peetakse teisejärguliseks loominguks. Nii võis ainult tema, kellel ei olnud osadust Aadama eksimatuses, järele anda mao meelitustele. 
5. Seega peituvad loomises eneses naisele loomuomased puudused. Tema intelligentsi ulatus moodustab lõpuks "nõiduse aluspõhja". ${ }^{66}$

Tõlkinud Jaak Metsallik

Tõlgitud raamatust Harmening, Dieter 1991. Zauberei im Abendland: Vom Anteil der Gelehrten am Wahn der Leute. Skizzen zur Geschichte des Aberglaubens. Quellen und Forschungen zur europäischen Ethnologie. Würzburg: Köningshausen \& Neumann.

\section{Kommentaarid}

${ }^{1}$ Duerr, Hans-Peter 1978 (1985). Über die Grenzen der Völkerkunde oder: Können Hexen fliegen? Zeitschrift für Parapsychologie 20; kordustrükk: H.-P. Duerr 1985. Satyricon: Essays und Interviews. Erweiterte Neuausgabe (= edition suhrkamp 1346). Frankfurt am Main, lk 12-29.

2 "Esimene selliste [nõia]salvide kolmest liigist paneb uskuma - pärast seda, kui keha on punaseks minemiseni sisse hõorrutud - , et ollakse õhku tõstetud. Keskaegsed müstikud rääkisid sellisel puhul levitatsioonist." Duerr, Hans-Peter 1978. Über die Grenzen der Völkerkunde oder: Können Hexen fliegen? Zeitschrift für Parapsychologie 20, lk 12.

${ }^{3}$ Lecouteux, Claude 1985. Hagazussa - Striga - Hexe. Hessische Blätter für Volks- und Kulturforschung 18, lk 57-70.

${ }^{4}$ Kramer (Institoris), Heinrich 1906. Malleus Malleficarum. Tõlge saksa keelde J. W. R. Schmidt Der Hexenhammer. Berlin 1906, kordustrükk Darmstadt 1974; vrd Harmening, Dietrich 1991. Die Hexe des Hexenhammers Literarische Kombinationen. Zauberei im Abendland. Würzburg, lk 60-69.

${ }^{5}$ Järgnev teosest: Harmening, Dieter 1983. Magie (Von der Spätantike zur Renaissance). Kindlers Enzyklopädie IV.'Der Mensch'. Zürich, lk 691-692.

${ }^{6}$ Hopfner, Theodor 1921. Griechisch-ägyptischer Offenbarungszauber. Studien zur Paleographie und Papyruskunde 21 \& 23. Leipzig. Kordustrükk: Amsterdam 1974, lk 19 jj, 223.

${ }^{7}$ Augustinus. De vivitate Dei II, lk 4, 24-25.

${ }^{8}$ Daemonum eam esse naturam, ut aerii corporis sensu terrenorum corporum sensum facile praecedant, celeritate etiam propter eiusdem aerii corporis superiorem mobilitatem non solum cursus quorumlibet hominum uel ferarum, uerum etiam uolatus auium inconparabiliter incant. Augustinus. De divinatione daemonum, c. 3, CSEL (= Corpus scriptorum ecclesiasticorum latinorum. Wien 1866 jj), lk 41, 603; vrd Hrabanus Maurus. De magicis artibus. PL (= Jacques-Paul Migne. Patrologia latina. . Paris 1878 jj), lk 110, 1102. 


\section{Dieter Harmening}

${ }^{9}$ Nad hiilivad õhkõrnade vaimudena salaja isegi kehadesse ja põhjustavad haigusi, hirmutavad hingi, moonutavad liikmeid, et neid end austama sundida. Minucius Felix. Octavius, c. 27, tõlgitud raamatust Bibliothek der Kirchenväter. $1911 \mathrm{jj}$.

${ }^{10}$ [---] quibus duabus rebus, quantum ad aerium corpus attinet, praediti, hoc est acrimonia sensus et celeritate motus, multo ante cognita praenuntiant uel nuntiant, quae homines pro sensus terreni tarditate mirentur. Augustinus. De divinatione daemonum, c. 3, CSEL (= Corpus scriptorum ecclesiasticorum latinorum. Wien 1866 jj) 41, 603; vrd. Hrabanus Maurus. De mag. art., toim PL (vt märkus 8): 110, 1101.

${ }^{11}$ Civ. Dei IX 22; accesit etiam daemonibus per tam longum tempus, quo eorum uita protendi-tur, rerum longe maior experientia, quam potest hominibus propter breuitatem uitae prouenire. per has efficacias, quas aerii corporis natura sortita est, non solum multa futura praedicunt daemones, uerum etiam multa mira faciunt, Augustinus. De divinatione daemonum, c. 3 , CSEL (= Corpus scriptorum ecclesiasticorum latinorum. Wien $1866 \mathrm{jj}$ ) 41, 604; vrd Hrabanus Maurus. De mag. art. toim PL (vt märkus 8): 110, 1101.

${ }^{12}$ Augustinus. De civitate Dei IX 21 jj, vrd Harmening, Dieter 1979. Superstitio. Überlieferungs- und theoriegeschichtliche Untersuchungen zur kirchlich-theologischen Aberglaubensliteratur des Mittelalters. Berlin, lk 176.

${ }^{13}$ Muu hulgas Minucius Felix. Octavius, c. 26; Lactantius. Epitome div. inst. c.23; Augustinus. Civ. Dei XXI 6; Hrabanus Maurus. De mag. art.; Thomas v. Aquin. Summa theologiae II: 94, 4.

${ }^{14}$ Augustinus. De civitate Dei VIII: 19, 20; X: 12.

${ }^{15}$ Quae cum ita sint, primum sciendum est, quoniam de diuinatione daemonum quaestio est, illos ea plerumque praenuntiare, quae ipsi facturi sunt accipiunt enim saepe potestatem et morbos inmittere et ipsum aerem uitiando morbidum reddere et peruersis atque amatoribus terrenorum commodorum malefacta suadere, de quorum coribus certi sunt, quod sint eis talia suadentibus consensuri. Augustinus. De divinatione daemonum, c. 3, CSEL (= Corpus scriptorum ecclesiasticorum latinorum. Wien 1866 jj) lk 41, 607.

${ }^{16}$ [---] aliquando autem non quae ipsi faciunt, sed quae naturalibus signis futura praenoscunt, quae signa in hominum sensus uenire non possunt, ante preaedicunt. neque enim quia praeuidet medicus, quod non praeuidet eius artis ignarus, ideo iam diuinus habendus est. quid autem mirum, si quemadmodum ille in corporis humani uel perturbata uel modificata temperie seu bonas seu malas futuras praeuidet ualitudines. sic daemon in aeris affectione atque ordinatione sibi nota, nobis ignota futuras praeuidet tempestates. Augustinus. De divinatione daemonum, c. 3, CSEL (= Corpus scriptorum ecclesiasticorum latinorum. Wien $1866 \mathrm{jj}$ ) lk $607 \mathrm{jj}$. 
${ }^{17}$ Vergilius. Aeneis IV: 484-488. Tõlk Ants Oras. Hortus Litterarum. Tallinn 1992.

${ }^{18}$ Augustinus. De civitate Dei XXI: 6, tõlk Carl Johann Perl, 3. köide. Salzburg 1953, lk 426-428.

${ }^{19}$ Toim CSEL 80 (vt märkus 8), tõlge raamatust Bibliothek der Kirchenväter (vt märkus 9).

${ }^{20}$ Augustinus. De doctrina christiana II: 20, tõlge raamatust Bibliothek der Kirchenväter (vt märkus 9): 49, 77. Samuti ka Ivo von Chartres. Decretum. P. XI. c. 13, toim PL (vt märkus 8): 161, 748.

${ }^{21}$ Augustinus. De doctrina christiana II: 20, tõlge raamatust Bibliothek der Kirchenväter (vt märkus 9): 49, 77. Thomas von Aquin. Summa theologiae II: 92-96, pass.

${ }^{22}$ Thomas von Aquin 1855. Quaestiones disputatae de malo, qu. 16. art. 9., toim Opera omnia. 15. Parmae.

${ }^{23}$ Augustinus. Contra Faustum 19: 11, toim CSEL (vt märkus 8).

${ }^{24}$ II 3, 3, toim PL (vt märkus 8): 40, 144.

${ }^{25}$ F. Hofmann 1933. Der Kirchenbegriff des hl. Augustinus. München, lk 341.

${ }^{26}$ Die gestriegelte Rockenphilosophie 1718. I-IV. Chemnitz.

${ }^{27}$ Die gestriegelte Rockenphilosophie 1718. I-IV. Chemnitz, eessõna.

${ }^{28}$ Vrd märkus 4.

${ }^{29}$ E. D. Hauber $1838-1745$. Bibliotheca sive acta et scripta magica etc. IIII. Lemgo; tsit. Schmidt. Eessõna raamatule: Kramer (Institoris), Heinrich 1906. Malleus Malleficarum. Tõlge saksa keelde J. W. R. Schmidt Der Hexenhammer. Berlin, lk VIII.

${ }^{30}$ Kramer (Institoris), Heinrich 1906. Malleus Malleficarum. Tõlge saksa keelde J. W. R. Schmidt. Der Hexenhammer. Berlin, lk 98.

${ }^{31}$ Vrd Adolph Franz 1898. Der Magister Nikolaus Magni de Jawor. Ein Beitrag zur Literatur- und Gelehrtengeschichte des 14. und 15. Jahrhunderts. Freiburg, lk 175. Järgneva kohta Harmening, Dieter 1970. Aberglaube und Alter. Skizzen zur Geschichte eines polemischen Begriffes: Volkskultur und Geschichte. Festschrift für Josef Dünninger. Toim Dieter Harmening \& Gerhard Lutz \& Bernhard Schemmel \& Erich Wimmer. Berlin, lk 211 jj.

${ }^{32}$ Samas, lk 155.

${ }^{33}$ Samas.

${ }^{34}$ Augsburg 1484, Kap 10; pärit Geffcken, Johannes 1855. Der Bildercatechismus des fünfzehnten Jahrhunderts und die catechetischen Hauptstücke in dieser Zeit bis auf Luther. Leipzig, lk 108-116, siin lk 112. 


\section{Dieter Harmening}

${ }^{35}$ Ipse quidem mulieres nunquam vigent in racione et intelligentia quam viri, et hinc est quod magis istis supersticionibus illaqueate tenentur et difficilius amoventur. Franz, Jawor (vt märkus 31), lk 155, märkus 2.

${ }^{36}$ Hieronymus. Comment. in ev. Matth. lib. IV., ad c. 23, v. 6, toim PL (vt märkus 8) lk 26, 168; vrd Cicero. Oratio de domo sua, c. 40, toim G. Peterson 1910. M. Tvlli Orationes. V. Oxonii, lk 39: Quid tibi necesse fuit anili superstitione, homo fanatice, sacrificium, quod alienae domit fieret, invisere? quae autem te tanta mentis imbecilliats tenuit ut non putares deos satis posse placati nisi etiam muliebribus religionibus te implicuisses?

37 [---] si enim feminae sexus infirmitate labuntur nam interdum isti muliebrem aut anilem superstitionem uocant - uiri certe sapiunt. Lactantius. Divinae institutiones. V 13, toim. CSEL (vt märkus 8), lk 439.

${ }^{38}$ Vrd Minucius Felix. Octavius, c. 13,5; Lactantius. Div. inst. V: 2 \& 13; Id., Epitome div. inst. 17; Augustinus. De civitate Dei IV: 30.

39 [---] qui totos dies praecabantur et immolabant, ut sui sibi liberi superstites essent, superstitiosi sunt appelati [---] Qui autem omnia, quae ad cultum deorum pertinerent, diligenter retractarent et tamquam relegerent, sunt dicti religiosi. Cicero. De natura deorum II 28, toim A. S. Paese. Cambridge \& Massachusetts 1958.

${ }^{40}$ Etymologiae. X 244; vrd G. Goetz. Corpus glossariorum latinorum V. Lipsiae et Berolini 154; Superstitiosus. ayt cicero ap qui totos dies precabantur et in molabant. ut sibi sui liberi subprestites essent, 11. sajandi marginaal.

${ }^{41}$ Cicero. De divinatione. II: 72, toim Arthur Stanley Pease 1920-1923; kordustrükk Darmstadt 1963; vrd Georg Heinrich Moser (tõlk) 1828. Cicero. Zwei Bücher von der Weissagung. Stuttgart.

${ }^{42}$ Cicero 1960. De finibus bonorum et malorum I: 60, tõlk ja toim Alexander Kabza. München, lk 60.

${ }^{43}$ Exameron. IV 32. toim CSEL (vt märkus 8) XXXII: 1, lk 138-139.

${ }^{44}$ Ego tamen hanc fabulam rejicio ut popularem, utque ab aniculis introductam in mulierem coetum, Basileios d. Gr. 1867. De invidia 4. (toim PG (= Jaques-Paul Migne. Patrologia graeca. Paris), lk 31.

${ }^{45}$ Et nos possumus dicere in veritate, quia avia nostra, id est error antiquus et gentilis stultitia hoc dicebat. Tractatus IV. Contra paganos (toim PL (vt märkus 8)), lk 57, 783.

${ }^{46}$ Harmening, Dieter. Aberglaube und Alter (vt märkus 31). Lk 218.

${ }^{47}$ pagani erubescant pro tam absurdis opinionibus. Daniel von Winchester. Bonifatii ep. 23 (toim MGEp (= Monumenta Germaniae historica. Epistolae III [II. ed.])), lk 272. 
${ }^{48}$ De correctione rusticorum, qui cum fideles essent, honorem exhibeant idolis, C. W. Barlow (toim) 1950. Martini episcopi Bracarensis opera omnia. New Haven.

${ }^{49}$ Didymus. De Trinitate II, c. 12 , III, c. 17 , toim PG (vt märkus 44), lk 39, 384, 867; antiqum illud delictum. Pelagius. In Rom V, c. 12, Souter, A. (toim) 1926. Cambridge, lk 46.

${ }^{50}$ Jeremias der Propheta sprach: Opposuisti nubem, ne transeat oratio, herre got, sprach er, du hast ein wolken gesazt zwischen uns und dich, daz unser gebeth dar zu dir nicht moge comen. daz wolken nam unser herre Jhesus Christus dar von mit sinem tode. Anton E. Schönbach. Predigten I: 179; vrd Gregor von Nazianz. Orat. theol. XXVII: 12.

${ }^{51}$ Theophilus von Antiochen. Ad Autolycum II: 28; Athenagoras von Athen. Apol. 22; Origines in Rom. V: 12; Athanasius. Contra gentes 7 sq.; Cyrill von Jerusalem. Cat. VI: 11 jj; Augustinus. De civ. Dei XXI: 14; Gregor von Tours. Historiarum liber 5; Pirmin. Dicta 2-4.

${ }^{52}$ Augustinus. De civ. Dei XIV: 11, vrd Perl. Zur Psychologie des Sündenfalls; vrd A. Solignac. La Condition de l'homme pécheur d'aprés saint Augustin. Nouvelle Revue théologique 88 (1956), lk 367-476.

${ }^{53}$ I 3, C. 37 (73), toim PG (vt märkus 44), lk 643.

${ }^{54}$ N. Brox 1967. Antignostische Polemik bei Christen und Heiden: Münchener Theologische Zeitschrift 18, lk 285. "Gnostiseeriva" Tooma evangeeliumi (umbes $200 \mathrm{pKr}$ ) sarnase mahategeva hoiaku kohta vrd Ernst Werner \& Martin Erbstößer 1986. Ketzer und Heilige. Das religiöse Leben im Hochmittelalter. Wien \& Köln \& Graz, lk 15.

${ }^{55}$ Brox, N. 1967. Antignostische Polemik bei Christen und Heiden: Münchener Theologische Zeitschrift 18, lk 285-286.

${ }^{56}$ Phaidros 224b.

${ }^{57}$ Ep. VII: 335 a; lisaks vt N. Brox 1967. Antignostische Polemik bei Christen und Heiden: Münchener Theologische Zeitschrift 18, lk 286-287.

${ }^{58}$ Vrd Harmening, Superstitio (vt märkus 12), lk 300-301.

${ }^{59}$ Augustinus. De civ. Dei XIV: 11, tõlk Perl (vt märkus 18) 3. kd, 356. Zur Psychologie des Sündenfalls, vrd märkus 52.

${ }^{60}$ Anselm von Canterbury 1946. Proslogion, c. 1 (toim F. S. Schmitt \& S. Anselmi). Cantuariensis archiepiscopi opera omnia. I. Edinburg, tõlge saksa keelde E. Happ.

${ }^{61}$ Vrd Dieter Harmening. Zauberei im Abendland, lk 60-69 (vt märkus 4).

${ }^{62}$ Kramer (Institoris), Heinrich 1906. Malleus Malleficarum. Tõlge saksa keelde J. W. R. Schmidt. Der Hexenhammer. Berlin, lk 98. 
${ }^{63}$ Kramer (Institoris), Heinrich 1906. Malleus Malleficarum. Tõlge saksa keelde J. W. R. Schmidt. Der Hexenhammer. Berlin, lk 99.

${ }^{64}$ Kramer (Institoris), Heinrich 1906. Malleus Malleficarum. Tõlge saksa keelde J. W. R. Schmidt. Der Hexenhammer. Berlin, lk 99.

${ }^{65}$ Kramer (Institoris), Heinrich 1906. Malleus Malleficarum. Tõlge saksa keelde J. W. R. Schmidt. Der Hexenhammer. Berlin, lk 100.

${ }^{66}$ Kramer (Institoris), Heinrich 1906. Malleus Malleficarum. Tõlge saksa keelde J. W. R. Schmidt. Der Hexenhammer. Berlin, lk 100. 